\title{
The Eocene Bryozoans of Bekrit-Timahdite Formation, Middle-Atlas, Morocco: Taxonomy, Paleoenvironments and Paleoclimates Implications
}

\author{
Mohammed El Attmani ${ }^{*}$, Amine Bouwafoud1', Salem Elouariti' ${ }^{1}$, Hicham Si Mhamdi², \\ Abdelmajid Ben Bouziane1, Mustapha Mouflih ${ }^{1}$ \\ ${ }^{1}$ Sedimentary Basins Dynamic and Geological Correlations Laboratory, Department of Geology, Faculty of Science Ben M’sik, \\ Hassan II University, Casablanca, Morocco \\ ${ }^{2}$ Laboratory of Applied Geology, Department of Geosciences, Faculty of Sciences and Techniques Errachidia, Moulay Ismail \\ University, Meknes, Morocco \\ Email: ^elattmanim@gmail.com
}

How to cite this paper: El Attmani, M., Bouwafoud, A., Elouariti, S., Mhamdi, H. S., Bouziane, A. B., \& Mouflih, M. (2021). The Eocene Bryozoans of Bekrit-Timahdite Formation, Middle-Atlas, Morocco: Taxonomy, Paleoenvironments and Paleoclimates Implications. Journal of Geoscience and Environment Protection, 9, 136-153. https://doi.org/10.4236/gep.2021.93008

Received: December 8, 2020

Accepted: March 16, 2021

Published: March 19, 2021

Copyright $\odot 2021$ by author(s) and Scientific Research Publishing Inc. This work is licensed under the Creative Commons Attribution International License (CC BY 4.0).

http://creativecommons.org/licenses/by/4.0/ (c) $\underset{\mathrm{By}}{\mathrm{i}}$ Open Access

\begin{abstract}
Located in the North-West of the African continent, the Moroccan Middle Atlas constitutes an intra-continental chain within the Atlas domain. It is known by several global geological events such as the Paleocene-Eocene crisis during the Paleogene, which corresponds to one of the hottest periods on earth with Paleocene-Eocene thermal maximum (PETM). A taxonomic study carried out on the carbonate deposits of the Bekrit-Timahdite Formation from three sections of the Bekrit syncline allowed the identification of 5 species of the Cheilostome and Cyclostome Bryozoans (Cellaria rigida, Cellaria sinuosa, Aimulosia lamellosa, Heteropora and Osthimosia) in bioclastic limestones, nodular limestones, marly and sandy limestones. The interest of Bryozoans as indicators of paleoenvironments and paleoclimates was assessed by examining current communities, in terms of depth evolution as richness and abundance, distribution of taxonomic categories zoarium types, and zooidal morphology. The depositional environment analysis of Bryozoans showed a shallow marine carbonate platform with low sedimentation energy where is registered a relatively warm paleoclimate.
\end{abstract}

\section{Keywords}

Bryozoans, Eocene, Taxonomy, Carbonate, Paleoenvironment, Middle-Atlas 


\section{Introduction}

The shallow marine carbonate deposits of the Bekrit-Timahdite Formation are largely developed in the Bekrit syncline. It contains faunal assemblages, dominated by Bryozoans which are aquatic invertebrates that live in colonies. They represent a biological diversity in the carbonate deposits of the Middle Atlas during the Paleogene period. Most Bryozoans taxa live in warm shallow marine waters with low sedimentation energy (Rosso \& Sanfilippo, 2000; Hara, 2001; McKinney \& Taylor, 2003; Ziko et al., 2010; Gordon \& Taylor, 2015; Martha et al., 2016; Muftah \& El-Safori, 2019; Ernst et al., 2019).

Cheilostome and Cyclostome bryozoans are the most responsive in the Bekrit syncline. They have been previously listed by Herbig (1991). In this study a particular interest is given to the well-preserved species in bioclastic limestones.

The aim of this study is to identify and try to understand the distribution of Bryozoan's fauna in the bioclastic limestones of the Bekrit-Timahdite Formation. They will be studied in more taxonomic detail in order to define and clarify their true roles in the conservation of benthic habitats and ecosystems and in the end to determine paleoenvironment and paleoclimate.

Taxonomic diversity and a revision of some morphological notions of Paleogene Bryozoans in the Moroccan Middle Atlas were made for each group. Thus, the surveys carried out allowed us to begin the revision for Cyclostmes end Cheilostomes Bryozoans. Several colonies of Cheilostomes are characteristic of a subtropical to tropical climate (Ryland \& Hayward, 1977; Winston, 2004; Grischenko et al., 2007; Key et al., 2019). They have a zooecial polymorphism, formed by autozooïds performing the function of nutrition and heterozoïds represented by avicularium without Polypiers and unable to feed themselves (Ayari et al., 2008; Ayari et al., 2012; Ziko et al., 2016).

\section{Geological Setting}

The Moroccan Middle Atlas is the north most mountain of the Atlas system, oriented NE-SW along an average $350 \mathrm{~km}$. Located between the first hills of the Rif in the North and by the chain of the High Atlas in the South; it divides the Moroccan Meseta domains to the Eastern Meseta and Western Meseta. The Middle Atlas is the result of the Alpine events related to the opening of the Central Atlantic followed by the Alpine shortening. It was speared by the attempts of Triassic openings and the remobilization of the late variscan major faults zones (Ait Sliman, 1989; Herbig, 1991). Its structural-sedimentary evolution from the Jurassic to the present day was established by Fedan (1988) and Ait Sliman (2004). These authors describe two stages of structural-sedimentary evolution:

- Structuring of intraplate basins during the Jurassic in relation to the Mesogeia;

- Genesis of the intra-continental chain with Atlantic and then Mediterranean dependence.

The Middle Atlas is subdivided into two domains: the Southern Middle Atlas 
and the Northern Middle Atlas (Choubert \& Marçais., 1952). The latter is subdivided into two sub-domains separated by the Northern Middle Atlas fault (Termier, 1936):

1) The Middle Atlas Causse is characterized by the predominance of relatively flat carbonate layers of the Middle Jurassic (Charroud, 1990; Herbig, 1993). They are divided into faulted blocks along several NE-SW faults. The carbonate deposits of the Middle Atlas Causse are covered in many areas by Plio-quaternary basaltic flows from numerous volcanic apparatuses (Moukadiri, 1983; Harmand \& Cantargel, 1984; Harmand \& Mokadiri, 1986, El Azzouzi el al., 2010; Moutaj et al., 2019).

2) The folded Middle Atlas corresponds to the highest reliefs forming mountains oriented NW-SE (e.g.: Jbel Bounacer $3340 \mathrm{~m}$ and Jbel O-Salah $3190 \mathrm{~m}$ ). These mountains form anticlines along major faults zone that turn locally into anticline ridge. The tight anticlines are separated by a large four synclines (Figure 1): The Bekrit Syncline (El Koubbat Syncline), the Bou Anguer Syncline, the Ain Nokra Syncline, and the Oudiksou Syncline (Tighboula Syncline). They

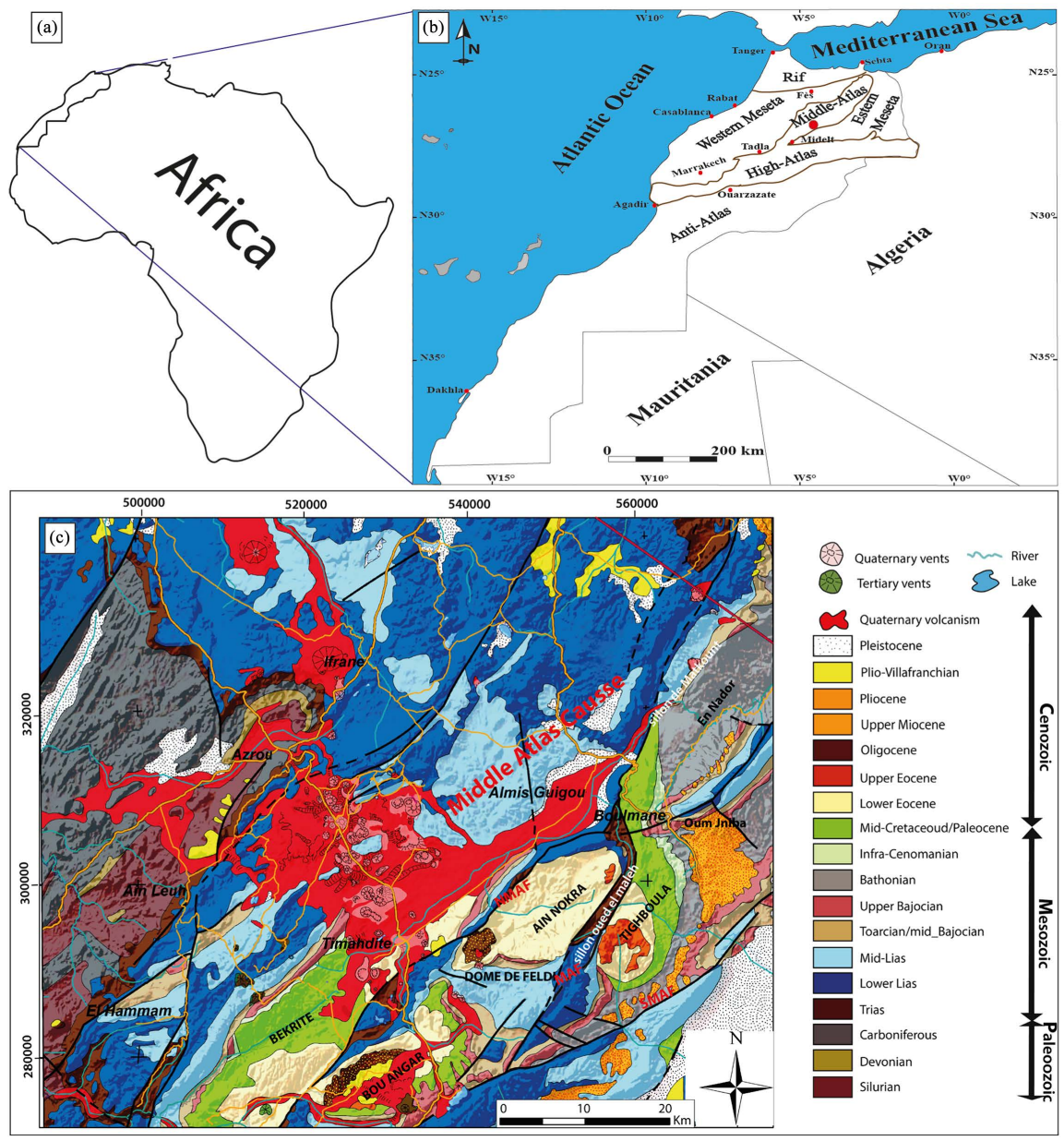

Figure 1. Geographical location from Morocco to the African continent (a); the location of the Middle Atlas in the Moroccan Atlas domain (b); Geological map of the folded Middle Atlas according to Mountaj et al. (2019) (c). 
are characterized by Cretaceous and Paleogene sedimentation (Charrière, 1990; Herbig, 1991; Herbig, 1993; Juidette, 2000; Mouflih et al., 2006; Mouflih, 2015; Charrière \& Haddoumi, 2016).

The Middle Atlas is fractured by several major fault zones; the most important is the Northern Middle Atlas Fault (N.M.A.F), the latter corresponds to a major lineament underlined by a crest line marking to the first Colo anticline ridge (Colo, 1961-1964).

This fault separates the Tabular Cause to the NW from the folded Middle Atlas to the SE. It is materialized by the lines of relief; from SW to NE we distinguish Jbel Hayane, Foum Khneeg, Jbel Tisdadine, Jbel Ben Ij, cluse of Oued Derdourah and Jbel Tajda. The Northern Middle Atlas Fault (NMAF) played an important role in the tertiary sedimentation identifying a different stratigraphy. It separates a domain with a Cretaceous series and a domain without the Cretaceous series (Charrière, 1990; Herbig, 1991; Herbig, 1993; Juidette, 2000; Ait Sliman, 2004; Moutaj et al., 2019).

In the Bekrit Syncline (El Koubbat Syncline), located to the North of the Northern Middle Atlas Fault (NMAF), the Paleogene deposits in accordance with the Upper Cretaceous. The latter is made up of five Formations, of which El Koubbat Formation is the only one represented only in the Bekrit Syncline. It is characterized by bituminous and phosphate carbonate sedimentation (Mouflih et al., 2006; Mouflih, 2015; Chakir et al., 2019).

In the Bou Angueur syncline, Cretaceous and Paleogene deposits begin with the Foum Khneeg Formation which lies in angular unconformity of the Middle Jurassic. The Foum Khneeg Formation is represented by phosphate limestone, marls, siltstones and silty-phosphate and marly-phosphate. This Formation is comparable to the Irbzer Formation, which is not outcropping in the Bou Angueur syncline (Figure 3). The age of this Formation is spread between the Maastrichtian and the Danian (Colin \& Tubace, 2004; Mebrouk et al., 2009).

The Bekrit-Timahdite Formation (subject of this study) overlies the Irbzer continental Formation. It outcrops in the residual basins of Bekrit-Timahdite, Bou Anguer, Ain Nokra and Oudikssou. It is named the Sub-Atlas group by Herbig (1991). This Formation is characterized by carbonate sedimentation that shows stratiform stylolitisation, formed by bioclastic limestone, sandstone, nodular limestone, marly limestone, lumachelle and lumachellic limestone in various colors (yellow, grey, white, pink and red). These limestones are grouped in filling cycles and show a decrease in the depth of the slice of marine water (Herbig \& Trappe, 1994; Herbig \& Fechner, 1994). The total thickness of the Bekrit-Timahdite Formation hardly exceeds 230 meters and varies between the different residual basins due to syn-sedimentary tectonic activity of all major faults (Figure 1).

The Bekrit-Timahdite Formation (Figure 2) was attributed to the Thanetian-Upper Lutetian (Choubert \& Marcais,1952), based on the study of Lamellibranches and Gastropods, while Herbig (1991) relates it to the Thanetian-Middle Eocene thanks to the presence of new Oysters Ostrea todraensis and 


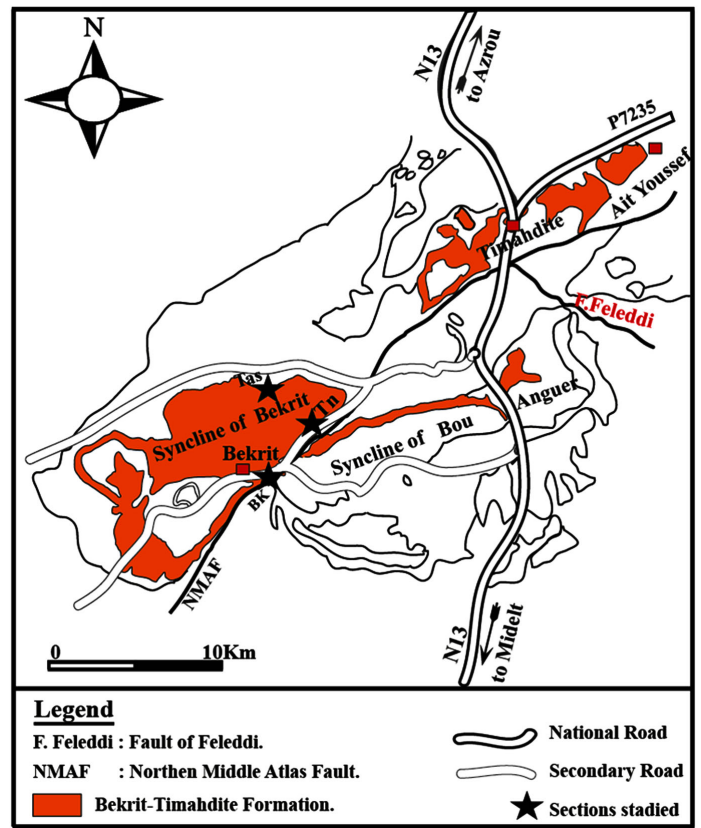

Figure 2. Location of the lithological sections studied in the Bekrit syncline. The Tasemakt section (TAS); the Bekrit section (BK); the Tizi N'Laafi section (Tn).

ostrea sidiliensis. The presence of a new species of green algae Triploporella atlasica $n$. $s p$, by Granier et al. (2002) at the Oudikssou syncline confirms the Lower and Middle Eocene age.

The Bekrit-Timahdite Formation is achieved in shallow marine limestones and covered by continental deposits of red gypsum marls of the Ain Nokra Group, named the Feleddi Formation. These deposits are attributed to the Upper Lutetian-Bartonian (Herbig, 1991; Herbig, 1993).

The Oudikssou formation is represented by a massif of micritic limestone rich on Charophytae and admitted of nodular silex. The base of this Formation shows to the first nodular silex limestone which is based on the Feleddi Formation, rich on bacterial laminae, fenestras and nodular structures. The presence of Foraminifera indicates the influence of the marginal sea (Herbig, 1991; Herbig, 1993; Ait Sliman, 2004).

The lateral variations of the Upper Cretaceous and Paleogene Formations of the Middle Atlas show an age ranging from the Maastrichtian to Upper Eocene (Herbig, 1991). In the Ain Nokra syncline (Felledi syncline), the Irbzer and Bekrit-Timahdit Formations are only exposed in the eastern part of the syncline. To the southwest, the Felledi Syncline Formations are intersected by Jurassic outcrops (Figure 3).

In the Oudiksou Syncline, the Irbzer Formation is reduced to the north and expands to the south. The Bekrit-Timahdite Formation bevels from North to South until the Oudiksou Formation rests directly on the Irbzer Formation.

\section{Materials and Methods}

The study was essentially field based on to ensure the collection of the latest 


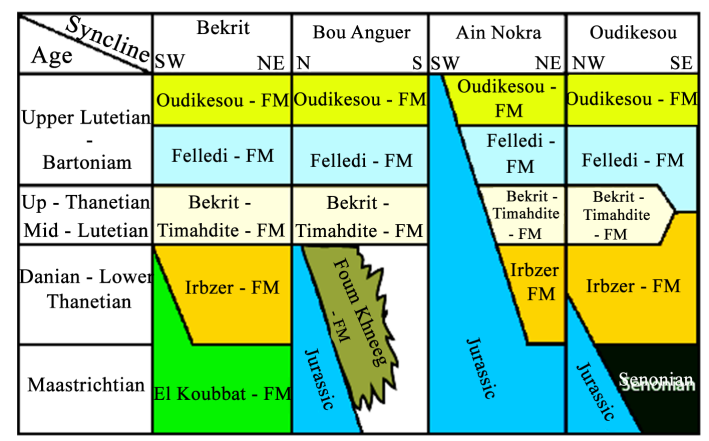

Figure 3. Lateral variations of the upper cretaceous-paleogene Formations of the middle atlas (Herbig, 1991).

geological measurement and samples data. However, an important part of the study was identification and determination of Bryozoans and interpretation of the results. The new data allowed a fresh approach towards the understanding of the geology of the study area.

Tree lithological sections were realized in the Bekrit Syncline. On the Northeast and Southwest, we have the Tasemakt section (X: 520,942 and Y: 520,942), the Bekrit section (X: 518,368 and Y: 275,244) and the Tizi N'Laafi section (X: 522,260 and Y: 279,388) within two lithological Formations: the red detrital of Irbzer Formation and the carbonate of Bekrit-Timahdite formation (Figure 2).

The petrographic study was carried out under a polarizing optical microscope on 45 thin sections prepared at Sedimentary Basin Dynamics and Geological Correlations Laboratory, Faculty of Sciences Ben M'sik, Hassan II University of Casablanca.

The petrographic analysis is based on microscopic observations in order to identify the different Genus and species of the Bryozoans fossils. The species were identified with reference mainly to MacGillivray (1885) and Brown (1958). Species identifications were difficult due to the random orientation of the colonies and the lack of access to the rich morphology of the front wall is essential to many species identifications.

\section{Results}

\subsection{Lithostratigraphic Analysis}

The Bekrit syncline is marked by Irbzer Formation-wish outcrops in the Tasemakt section (Figure 4). It is formed by red layers of clays, red marls and grey marls with clay intercalations that are alternated with evaporitic deposits of white fibrous gypsum.

The Bekrit-Timahdite formation is represented by yellow to beige carbonate deposits, with sandstone limestones, were unregistered oblique stratification with Wackestone to Packestone texture. The biofacies are built by Oyster fragments, Gastropods and Lamellibranches. The presence of oblique stratification and biofacies fragments indicates a depositional environment corresponds to tidal channel deposits in a tidal-flat, with relative agitated high-energy. Above 


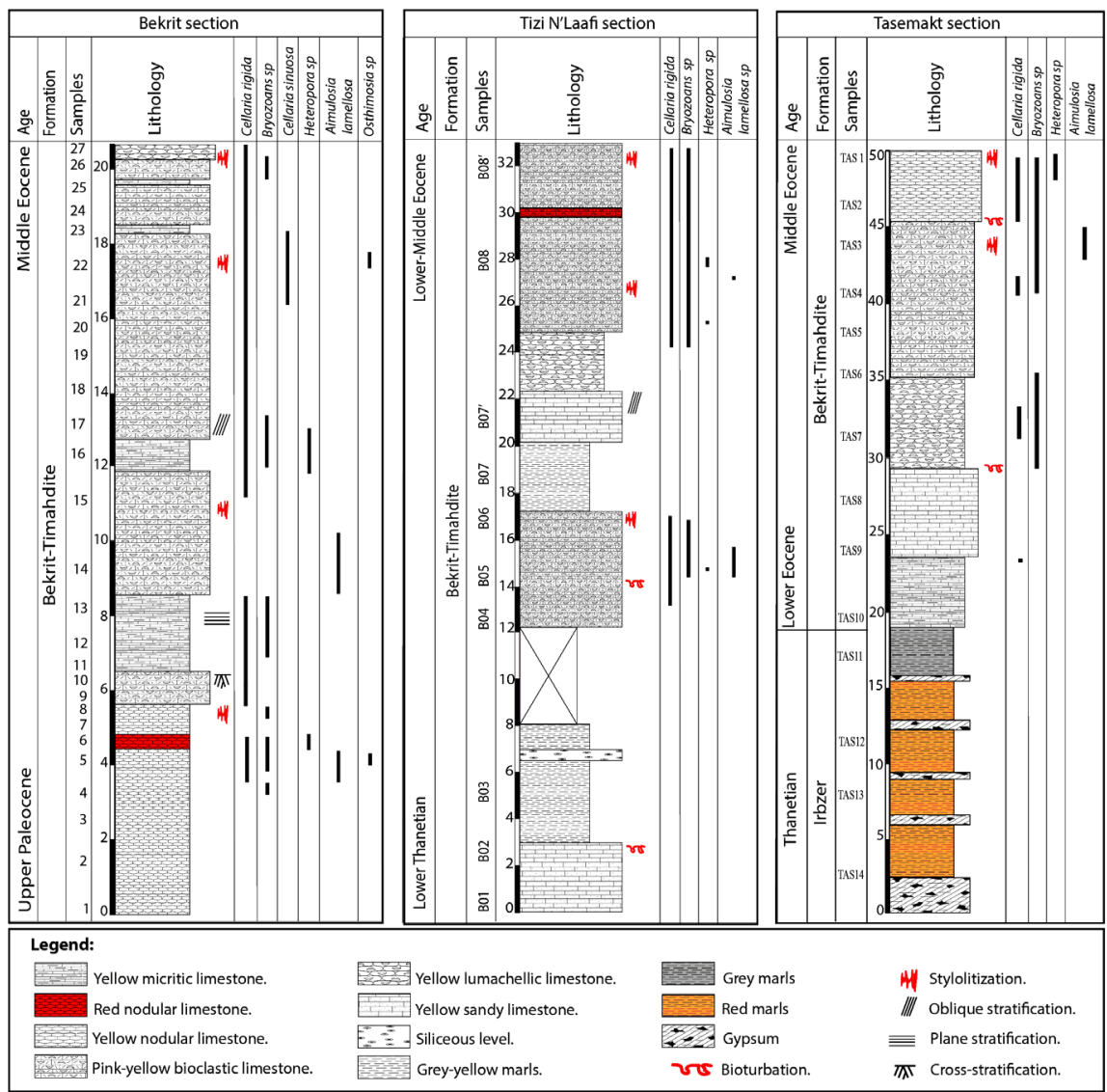

Figure 4. Lithological sections studied in Bekrit syncline, Middle-Atlas, Morocco.

the lumachellic limestones, rich on bioclasts; they were deposited in a shallow marine environment.

At the top there are white, yellow, gray and pink Bioclastic limestones facies, with Grainstone, Packestone and Wackestone to Packestone texture. The richness of bioclastes shows: Bryozoans, Green Algae frustules, Echinoderms plates, Benthic Foraminifera, Gastropods and Lamellibranchs and other bivalve shells, also it admitted stratiform stylolitization. Depositional environment is a shallow marine and relatively calm marine platform.

Nodular yellow, beige and red limestones are also present, with a Wackestone to Packestone texture, affected by stratiform stylolitization. The biofacies are built by Green Algae, Bryozoans, Benthic foraminifera, Echinoderms and rare bivalve shells indicating a shallow shelf marine environment. The presence of stylolites suggests that the nodule-like appearance of these limestones is due to the susceptibility of these levels to compaction during diagenesis (Ait Sliman, 2004).

\subsection{Paleontologic Taxonomy}

Phylum: Bryozoa Ehrenberg, 1831

Class: Gymnoalemata Allman, 1856

Order: Cheilostomata Busk, 1852 


\section{Suborder: Flustrina Smitt, 1868 \\ Superfamily: Cellarioidea Lamouroux, 1821 \\ Family: Cellaridae Fleming, 1828 \\ Genus: Cellaria Ellis \& Solander, 1786 \\ Cellaria rigida MacGillivray 1885}

(Plate 1(f)-(j))

Description: This species presents a thin colony erected and composed of broken rigid cylindrical segments (internodes). The autozooecia are arranged in longitudinal rows, relatively rhomboidal in shape but longer than wide;

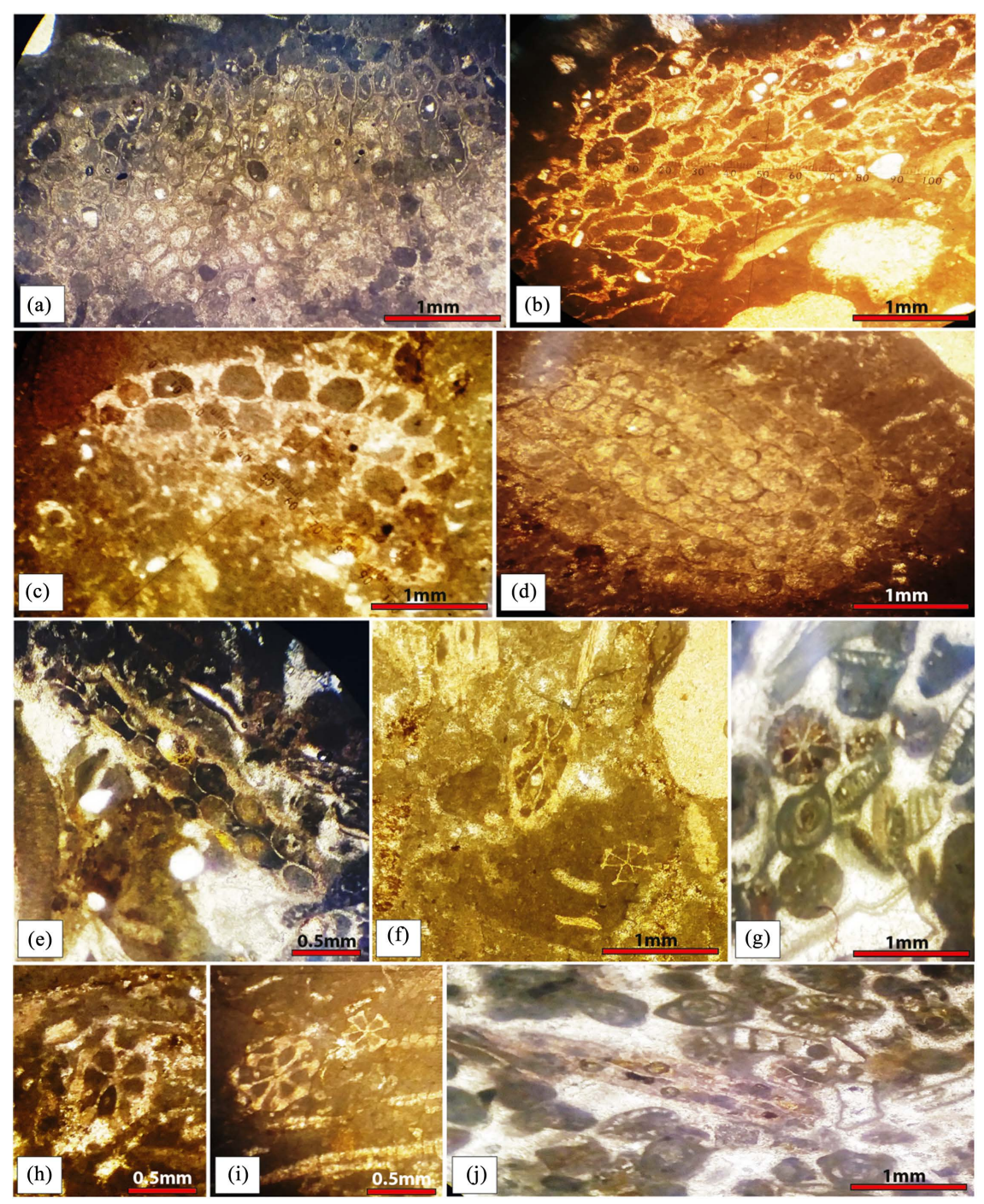

Plate 1. The Paleogene faunal assemblages of the Bekrit-Timahdite carbonate formation. (a): Cyclostome Bryozoans in micritic limestone, genus Heteropora de Blainville, 1830; (b): Biomicritic limestone with Bryozoan sp(Osthimosia sp); (c) and (d): Biomicritic limestone with Cheilostome Bryozoan, Aimulosia lamellosa sp. (Hara, 2000); (e): Bioclastic limestone with Cellaria sinuosa (Hassal, 1840), longitudinal section; (f)-(i): Biomicritical and biosparasitic bioclastic limestone with Bryozoans CheilostomEs, Cellaria rigida MacGillivray 1885, cross-section; (j): Biosparasitic bioclastic limestone with Cellaria rigida MacGillivray 1885 associated with Green algae and miliolida, longitudinal section. 
separated by thin ridges. The cryptocyst is granular, medially concave, with paired ridges flanking the opecia. Opecia are located in the distal half of the autozooecium, reniform with a rounded, slightly curved proximal lip; small, sharp, forward-projecting denticules in each proximal corner; a pair of larger denticules present in the distal border, joined by the ridge with a characteristic depression in the middle part of the ridge.

Dimensions: Colony length of $10 \mathrm{~mm}$, width of the internodes from 0.35 to $0.50 \mathrm{~mm}$; length of the zooecia varies from $0.36 \mathrm{~mm}$ to $0.42 \mathrm{~mm}$, width from 0.34 to $0.42 \mathrm{~mm}$; width of the opecia fluctuates between 0.08 and $0.1 \mathrm{~mm}$ with a length of $0.3 \mathrm{~mm}$.

Remarks: The Cellaria rigida specimen studied shows all the characteristics of the genus Cellaria. Busk, 1884 described from recent faunas show several similarities with the species examined, such as a reniform opecia in the distal half of autozooecium, a low, rounded proximal lip, a blunt denticule projecting forward in each proximal corner, and a pair of smaller, pointed denticules present in a distal edge connected by a finely denticulated ridge. The specimen is distinguished by a slightly different shape from autozooecia, which are arranged in 10 longitudinal rows, rather than in 14 rows as observed for Cellaria clavata (Busk 1884).

Occurrence: Bioclastic limestone, Bekrit-Timahdite Formation, Bekrit section (samples 4 - 5; samples 8 - 13 and samples 15 - 27); Tizi N'Laafi section (samples B04-B06 and B08-B08') and Tasemakt section(samples TAS1-TAS2; TAS4; TAS6-TAS7), Middle Atlas, Morocco.

Distribution: Cellari rigida is reported in the Upper Paleocene-Middle Eocene of Middle Atlas (Morocco), Eocene of Australia, Oligocene of New Zeeland, Miocene of France.

\section{Cellaria sinuosa (Hassal, 1840)}

(Plate 1(e))

Description: The cellaria sinuosa species presents a sub-hexagonal to rounded autozooïd, elongated with broad ends and organized in at least 10 alternating longitudinal series (up to 16). Free zooarium, erected in a cylindrical shape. Finely granulated concave cryptocyst. Sub-rounded avicularuim, half the size of an autozooïd, with a hole closed by a chitinous operculum. Sub-terminal opesia, close to the distal part of zooecium. The rounded triangular mandible positioned obliquely to the axis of the cylindrical segments (internode). Ovicell completely immersed, not visible at the surface except for its rounded or irregular opening.

Dimensions: length of the zooecia varies between $0.44 \mathrm{~mm}$ and $0.47 \mathrm{~mm}$, width of the zooecia varies between $0.26 \mathrm{~mm}$ and $0.35 \mathrm{~mm}$; length of the opesia $0.08 \mathrm{~mm}$ and $0.1 \mathrm{~mm}$; width of the opesia varies between $0.09 \mathrm{~mm}$ and $0.13 \mathrm{~mm}$.

Remarks: This type of Cheilostomes Bryozoans forms soft bushes with a dichotomous branching that is distinct at the microscopic level. Colonies are dense clumps, more robust than other Cellaria fistulosa (Linnaeus, 1758) and other European Cellaria genus. In addition, the colony measures 4 to $5 \mathrm{~cm}$ in height. 
The cylindrical segments are often rigid. They are articulated and clearly swollen towards the distal end, which gives some flexibility to the colony.

Occurrence: Bioclastic limestone, Bekrit-Timahdite Formation, samples (21 23) Bekrit section, Middle Atlas, morocco.

Distribution: Cellaria sinuosa is reported in the Atlantic Ocean, Middle Eocene of Morocco Eocene of Tunisia, Oligocene-Miocene of Egypt and France, Pliocene of England, Italy, Portugal and Pleistocene of Italy.

Suborder Ascophora Levinsen, 1909

Superfamily Schizoporelloidea Jullien, 1883

Family Buffonellodidae Gordon et d'Hondt, 1997

Genus Aimulosia Jullien, 1888

Aimulosia australis Jullien, 1888.

Aimulosia lamellosa sp (Hara, 2000)

(Plate 1(c) and Plate 1(d))

Description: The colonies of these species are formed by massive zoaria, of variable shape, more or less elongated. The front wall is relatively unperforated, slightly convex. It rises distally in protrusion. The marginal areolar pores are large, prominent and variable in number. The autozooecia are arranged in somewhat radiating, alternating, elongated to irregularly hexagonal rows, separated by deep grooves. The centers of eruptive buds are often visible in the upper layers of the colony. The primary orifice is relatively hollow, subcircular in shape. The secondary orifice is large relative to zooecium size, semi-circular to somewhat semi-circular or sinuate with a very low, truncated trunk and wide, indistinct condyles. Oral spines as well as vicarious aviculars are absent. The multi-lamellar structure is very clear, both in external view and in the thin sections of the colonies.

Dimensions: Zooecia length $0.050-0.075 \mathrm{~mm}$, width $0.030-0.037 \mathrm{~mm}$; orifice length $0.10-0.125 \mathrm{~mm}$, avicularium length $0.06-0.07 \mathrm{~mm}$, width $0.056 \mathrm{~mm}$.

Remarks: The species studied show all the characteristics of the genus Aimulosia, such as the development of a secondary orifice with a rounded median tooth (Jullien, 1888), with a prominent unperforated ovicell (Gordon, 1989). The presence of medial convexity, in the proximal edge of the orifice, is not a constant feature in this species. It is undoubtedly a product of the state of preservation. According to Jullien (1888), this small median convexity in the proximal edge of the orifice corresponds to the lyrula of smittinids (Gordon 1989). However, Aimulosia has been included in the family Buffonellodidae Gordon and d'Hondt, 1997, in which the orifice has a median sinus or a large poster; the latter may have a median convexity.

The species studied lack additional avicularia and distal oral spines, which are very often present in other species of the genus. The specimens studied bear a slight resemblance to Porella marsupium (MacGillivray, 1869) by having a very similar architecture of the front wall (Gordon 1984: pl. 36B).

Occurrence: nodular limestone, bioclastic limestone, Bekrit-Timahdite Formation, Bekrit section (samples 4 - 5; samples 13 - 15); Tizi N'Laafi section 
(samples B05-B06; Samples B08)and Tasemakt section (samples TAS3-TAS4), Middle Atlas, Morocco.

Distribution: Upper Paleocene-Middle Eocene of Middle Atlas (Morocco), Eocene of Seymour Island, Antarctic Peninsula.

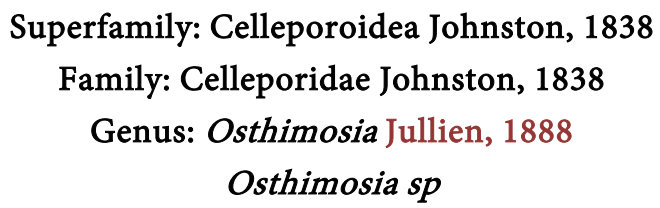

(Plate 1(b))

Description: The colony is encrusted, forming irregularly shaped zooariums attached to relatively hard substrates. The surface of the zooariums is variable and uneven. The autozooecia openings are at the same level as the general surface of the colony; sinuous in shape, some are pentagonal. The autozooecia openings are surrounded by convex plates of different shapes, slightly raised above the zooecial openings, with holes of variable size and shape. Interzooecial, rare avicularium. The highest parts of the zooarial surface bear some tubular avicular. The ovicles are absent.

Dimensions: colony width varies between $1.6 \mathrm{~cm}$ and $1.7 \mathrm{~cm}$; length of zooecia $0.16-0.20 \mathrm{~mm}$, width $0.16-0.21 \mathrm{~mm}$; length of interzooecial avicular 0.20 $\mathrm{mm}$, width $0.14 \mathrm{~mm}$; diameter of vicarious tubular avicular $0.14 \mathrm{~mm}$.

Remarks: The species studied bears a certain resemblance to the genus $\mathrm{Os}$ thimosia (Jullien, 1888) by the sinuous shape of the autozooecial openings, and by the position of small interzooecial avicular. The zooecial openings are of variable shapes and the absence of ovals allowed us to get to this species. Due to the rarity of diagnostic characters, the specimens examined are only provisionally included in the genus Osthimosia. It is also possible that the specimens studied represent new taxa.

Occurrence: Nodular limestone and bioclastic limestone, Bekrit section (Sample 5 and sample 22), Middle Atlas, Morocco.

Distribution: Upper Paleocene-Middle Eocene of Morocco, Eocene of Seymour Island, Antarctic Peninsula, Upper Eocene of Southeastern USA.

Class: stenolaemata Borg, 1926

Order: Cyclostomata Busk, 1852

Family: Cerioporidae Busk, 1859

Genus: Heteropora de Blainville,1830

Heteropra sp

(Plate 1(a))

Description: This species presents an erect colony, usually branched. The branches bifurcated robust. The diameter becomes wider in the autozooïdal bands, narrower in the areas between the bands that are spaced about $3 \mathrm{~mm}$ apart along the length of the branch. The proximal and distal endozooïdal walls of the units are not preserved. Free-wall autozooïds, hexagonal to subcircular or somewhat longitudinally elongated openings, large in size. They are generally separated by one or more free-wall kenozooïds, substantially smaller than the 
autozooïds, embedded under the polygonal edge formed by the interzooïdal walls.

Dimensions: Autozooïdal bands with a diameter of $2.3 \mathrm{~mm}$ to $3.4 \mathrm{~mm}$, autozooïdal openings from $0.22 \mathrm{~mm}$ to $0.25 \mathrm{~mm}$ with a diameter of $0.19 \mathrm{~mm}$ to 0.24 $\mathrm{mm}$. The inner opening diameter $0.03 \mathrm{~mm}-0.11 \mathrm{~mm}$, the outer diameter of the kenozooïd between zoïdal limits $0.09 \mathrm{~mm}-0.32 \mathrm{~mm}$.

Remarks: The problems of the taxonomic study of Cyclostomes Bryozoans of the Middle Atlas carbonate Formation are related to the fragmentary and worn-out conservation of most specimens, coupled with the uncertainties about the value of traditional skeletal traits raised by work on molecular phylogenetics of this order (Waeschenbach et al. 2009). The extensive thin sections required for detailed cyclostomes studies have not been undertaken. For these reasons, several attributions are provisional and full descriptions are not given for all species. Robust branches of an unidentified species of Heteropora include fertile specimens with blister-shaped circular gonozooids, covered by an outer wall pierced by isolated autozooidal peristomes.

Occurrence: nodular limestone and bioclastic limestone, Bekrit-Timahdite Formation, Bekrit section (sample 6; samples 15 - 17); Tizi N'Laafi section (samples B05-B08) and Tasemakt section (samples TAS1-TAS2), Middle Atlas, Morocco.

Distribution: Upper Paleocene-Middle Eocene of Middle Atlas (Morocco), Eocene of Seymour Island, Antarctic Peninsula, Upper Eocene of New Zeland, Missinian of Mellila basin (Morocco), Neogene of Britain, Neogene of france, Miocene of Sirt Basin, (Lybia).

\section{Discussions}

Bryozoans collected in the various carbonate sediments of the Bekrit-Timahdite Formation, particularly in the Bekrit syncline, constitute one of the richest faunas, both in number of individuals and in number of species currently known in Morocco. Their state of conservation makes it possible to draw some observations of a taxonomic, paleoenvironmental and paleoclimatic conditions.

The presence of Dasycladalean Green Algae and Siphonous Green Algae in association with Cheilostomes and Cyclostomes Bryozoans allow to attribute an age that spreads between the Upper Paleocene and Middle Eocene to the neritic sediments of the carbonate platform, Thus, the presence of five species of bryozoan (Cellaria rigida, Cellaria sinuosa, Heteropora $s p$, Osthimosia $s p$ and Aimulosia lamellosa $s p$ ) cannot specify, for the moment, this age for the deposits of the inner Paleogene platform. This is due to an insufficient knowledge of the Paleogene Bryozoans fauna. However, some considerations can be provided.

The carbonate succession of the Bekrit-Timahdite Formation is dated Upper Paleocene-Middle Eocene based on the presence of Foraminifera, Green Algae, Gastropods and calcareous nanofossils (Herbig, 1991; Granier et al., 2002; Ait Sliman, 2004). 
The presence of many Bryozoans is likely to provide valuable information on the environmental conditions of the carbonate layers that contain them. The moderate state of fragmentation and the low degree of wear of the Bryozoans colonies, the mineralized constituents of the other associated groups (frustules of Green Algae, shells of Gasteropods, Benthic Foraminifera, Brachiopods, the theques of Echinoderms) make it possible to envisage fossil assemblages whose elements, of various sizes, were deposited quickly after a relatively reduced transport. The relative dominance of the cellariiform group, mainly represented by the species Cellaria rigida (MacGillivray, 1885) and Cellaria sinuosa (Hassal, 1841), is the evidence of a low depth, which varies between 30 and 50 meters, indicating a shallow marine environment.

All the Bryozoans species studied are seaweed and are associated with other organisms such as Green Algae, Benthic Foraminifera (Miliolida), Echinoderms and bivalve shells. The richness and variety of the fauna as well as the presence of benthic forms suggest a frankly marine environment with relatively high salinity.

From a climatic point of view, the studied species of the Bryozoans fauna of the Moroccan Middle Atlas are characteristic of a tropical climate. Species from cold temperate regions are not represented. The presence of the bryozoans $\mathrm{Cel}$ laria rigida (MacGillivray, 1885) and Cellaria sinuosa (Hassal, 1841), warm sea species, the rather important presence of some representatives of the genus $\mathrm{He}$ teropora de Blainville1830 and the species Aimulosia lamellosa sp (Hara, 2000), currently found in tropical regions, as well as important formations of coralline algae, lead to say that the carbonate sedimentation of the Middle Atlas, indicates a relatively warm temperature in a tropical climate in a shallow environment. As indicated by Holcová and Zágoršek (2008), the main factor of Bryozoan's accumulation is probably the change in trophic conditions, as well as high temperature variability.

Macro/microfossil assemblages suggest a transgressive deposition medium in the inner neritic platform environment. The presence of low diversity bryozoans (Cellaria rigida., cellaria sinuosa., Heteropora and Aimulosia lamellosa) at some levels clearly indicates shallow waters with low sedimentation rates (El Safori, 2000; Mustah \& el-Safori, 2019).

Carbonates from the shallow marine environment developed extensively in the residual basins of the Middle Atlas during the Eocene. These shallow water carbonate environments have undergone significant changes, in platform architecture and sediment composition in the context of tectonic remobilization induced splitting, associated with significant ocean circulation and environmental changes, accompanied by sea-level rise (Masetti et al. 2016; Solak et al., 2017; Preto et al., 2017; Rychlinski et al., 2018; Franceschi et al. 2019). These events also coincided with the faunal recovery.

In the Middle Atlas, the Paleocene-Eocene passage is generally marked by relatively high carbonate productivity (Ait Sliman, 2004) with facies rich in marine microorganisms. The carbonate factory represented by Bryozoans, Echinoderms, 
Brachiopods and bivalves suggests well-oxygenated water with normal salinity under oligo- to mesotrophic conditions (Brigaud et al., 2009). Seawater paleotemperatures indicate a Paleocene-Eocene thermal maximum event (PETM). This seawater temperature may have favoured the development of carbonate production in the Eocene platform of the Bekrit syncline.

\section{Conclusion}

The shallow marine carbonates of the Bekrit-Timahdite carbonate Formation located in the Middle Atlas Mountains contained undiversified Bryozoans remains. The descriptive taxonomic study of the Bryozoans of the Bekrit syncline allows, in the first place, a contribution to the knowledge of this group in the Paleogene cycle, which is not well known at present. Five species belonging to the Cyclostome and Cheilostome could be collected in the 3 studied sections of carbonate Formation of Bekrit-Timahdite, in particularly in the two flanks of the Bekrit syncline.

The assemblages of the bryozoans taxa described here are indicative of warm shallow marine waters with relatively low energy. The taxa concerned have more or less extensive geographical distribution and live in a shallow marine environment in a relatively tropical climate. It is hoped that this information can be applied in the future to gain insight and understanding of the evolution of the Bryozoans organisms, which are common in the carbonate sediments of the Middle Atlas and compared to those of Tunisia and Egypt during the Eocene.

\section{Acknowledgements}

We acknowledge the Department of Geology, Faculty of Sciences Ben M'sik, Hassan II University of Casablanca, Morocco, for support and field expenses. We acknowledge the Head of the Department of Biostratigraphy and Sedimentary Petrography at ONHYM Dr. Zakaria Yousfi for his assistance in the construction of thin sections, preparation of documentation and microscopic observations. Andrej Ernst, University of Hamburg, Germany and Paul D. Taylor, Department of Earth Sciences, London, are acknowledged for their support, advice and guidance. We acknowledge our colleagues at Sedimentary Basins Dynamic and Geological Correlations Laboratory. We also acknowledge Dr. Hind Yaacoubi and Dr. Aida Rafai for their support and guidance during the writing of this article. We thank Professor EL Mostafa Benfrika, member of the Sedimentary Basins Dynamic and Geological Correlations laboratory for the reading and review of this work.

\section{Conflicts of Interest}

The authors declare no conflicts of interest regarding the publication of this paper.

\section{References}

Ait Sliman, M. A. (1989). Evolution structuro-sédimentaire Paléogène de la partie sud Ouest 
du Moyen-Atlas (Baqrit-Timahdit-Guigou-BouAnguer-Ain Nokra-Oudiksou) (p. 179). D.S.S. Univérsité Cadi Ayyad, Faculté des Sciences de Marrakech.

Ait Sliman, M. A. (2004). Le Paléogène du Moyen Atlas: Analyse, évolution et cadre géodynamique (p. 332). Thèse d'état, Casablanca: Université Hassan II Mohammedia.

Ayari, R., Afli, A., \& Aissa, P. (2012). Diversite taxonomique des bryozoaires cheilostomes au large du golfe de tunis (Vol. 39). Bull. Inst. Natn. Scien. Tech. Mer de Salammbô.

Ayari, R., Taylor, P., Afli, A., \& Aissa, P. (2008). A New Species of the Cheilostome Bryozoans. Trematooecia Osburn, 1940 from the Mediterranean Sea. Cahiers de Biologie Marine, 49, 261-267.

Brigaud, B., Durlet, C., Deconinck, J. C., Vincent, B., Pucéat, E., Thierry, J., \& Trouiller, A. (2009). Facies and Climate/Environmental Changes Recorded on a Carbonate Ramp: A Sedimentological and Geochemical Approach on Middle Jurassic Carbonates (Paris Basin, France). Sedimentary Geology, 222, 181-206. https://doi.org/10.1016/j.sedgeo.2009.09.005

Brown, D. A. (1958). Fossil Cheilostomatous Polyzoa from Southwest Victoria (pp. 1-90). Memoirs of the Geological Survey of Victoria No. 10.

Busk, G. (1884). Report on the Polyzoa Collected by H. M. S. Challenger during the Years 1873-76. Part 1. The Cheilostomata. Report on the Scientific Results of the Voyage of H. M. S. Challenger. Zoology, 10, i-xxiv, 1-216.

Chakir, S., Slimani, H., Hssaida,T., Kocsis, L., Gheerbrant, E., Bardet, N., Jalil, N. E., Mouflih, M., Mahboub, I., \& Jbari, H. (2019). Dinoflagellate Cyst Evidence for the Age, Palaeoenvironment and Paleoclimate of a New Cretaceouse Paleogene (K/Pg) Boundary Section at the Bou Angueur Syncline, Middle Atlas, Morocco. Cretaceous Research, 106, Article ID: 104219. https://doi.org/10.1016/j.cretres.2019.104219

Charrière, A. (1990). Héritage hercynien et évolution géodynamique alpine d'une chaine intracontinentale: Le Moyen Atlas au SE de Fès (Maroc) (p. 589). Thèse d'état, Université Paul Sabatier, Toulouse III (Sciences), 2 tomes.

Charrière, A., \& Haddoumi, H. (2016). Les Couches rouges continentales jurassico-crétacées des Atlas marocains (Moyen Atlas, Haut Atlas central et oriental): Bilan stratigraphique, paléogéographies successives et cadre géodynamique. Boletín Geológico y Minero, 127, 401-424.

Charroud, M. (1990). Evolution géodynamique de la partie sud-ouest du Moyen Atlas durant le passage Jurassique Crétacé, le Crétacé et le Paléogène (p. 232). Thèse 3ème cycle, Rabat: Université Mohammed V.

Choubert, G., \& Marcais, J. (1952). Aperçu structural in Géologie du Maroc. XIXéme Congés Géol. Inten., Alger, 1952, monogr Rég., 3ème série, Maroc, nº 6, 2 cartes, Notes et Mém. Serv. Géol., Maroc, $n^{\circ}$ 100, 9-73.

Colin, J. P., \& Tabuce, R. (2004). Ostracodes limniques dans la formation d'Irbzer, Crétacé terminal du Moyen-Atlas, Maroc: Taxonomie, biostratigraphie, paléoécologie, paléobiogéographie. Revue de Micropaléontologie, 47, 103-109.

https://doi.org/10.1016/j.revmic.2004.04.001

Colo, G. (1961-64). Contribution à l'étude du Jurassique du Moyen Atl as septentrional. 2 Volumes. Notes et Mém. Serv. Géol. Maroc, nº 139 bis, p. 226.

El Azzouzi, M., Maury, R. C., Bellon, H., Youbi, N., Cotten, J., \& Kharbouch, F. (2010). Petrology and K-Ar Chronology of the Neogene-Quaternary Middle Atlas Basaltic Province, Morocco. Bulletin de la Societe Geologique de France, 181, 243-257. https://doi.org/10.2113/gssgfbull.181.3.243

El Safori, Y. A. (2000). Early Eocene Bryozoans of the Farafra Oasis, Egypt (pp. 232-237). 
In H. C. Amalia, \& J. B. C. Jackson, Eds., Proceeding of the 11th International Bryozoology Association Conference. Balboa: Smithsonian Tropical Research Institute.

Ernst, A., Nasiri, Y., Carrera, M. G., Harami, R., Mahboubi, A., \& Mosaddegh, H. (2019). Bryozoan Fauna from the Mobarak Formation (Mississippian), Northern Iran. Paläontologische Zeitschrift. https://doi.org/10.1007/s12542-019-00504-8

Fedan, B. (1988). Evolution géodynamique d'un bassin intraplaque sur décrochements: Le Moyen Atlas (Maroc) durant le Méso-Cénozoïque (p. 338). Thèse Doctorat d'Etat, Rabat: Univ. Mohammed V.

Franceschi, M., Dal Corso, J., Cobianchi, M., Roghi, G., Penasa, L., Picotti, V. et al. (2019). Tethyan Carbonate Platform Transformation during the Early Jurassic (Sinemurian-Pliensbachian, Southern Alps): Comparison with the Late Triassic Carnian Pluvial Episode. Geological Society of America Bulletin, 131, 1255-1275.

https://doi.org/10.1130/B31765.1

Gordon, D. P. (1984). The Marine Fauna of New Zealand: Bryozoa: Gymnolaemata from the Kermadec Ridge (pp. 1-198). New Zealand Oceanographic Institute, Memoir 91.

Gordon, D. P. (1989). The Marine Fauna of New Zealand: Bryozoa: Gymnolaemata (Cheilostomida Ascophorina) from the Western South Island Continental Shelf and Slope (pp. 1-158). New Zealand Oceanographic Institute, Memoir 97.

Gordon, D. P., \& Hondt, J. L. (1997). Bryozoa: Lepraliomorpha and Other Ascophorina, Mainly from New Caledonian Waters. Memoires du Museum National d'Histoire Naturelle, 176, 9-124.

Gordon, D. P., \& Taylor, P. D. (2015). Bryozoa of the Early Eocene Tumaio Limestone, Chatham Island, New Zealand. Journal of Systematic Palaeontology, 13, 983-1070. https://doi.org/10.1080/14772019.2014.991905

Granier, B., Ait Sliman, M. A., \& Fedan, B. (2002). Validation de l'espèce Triploporella atlasica in Granier, B., Ait Sliman, M.A. \& Fedan, B., non 1997. Proceedings of the 4th IFAA Regional Meeting, Cluj-Napoca, 29 August-5 September 2001, 115-116.

Grischenko, A. V., Dick, M. H., \& Mawatari, S. F. (2007). Diversity and Taxonomy of Intertidal Bryozoa (Cheilostomata) at Akkeshi Bay, Hokkaido, Japan. Journal of Natural History, 41, 1047-1161. https://doi.org/10.1080/00222930701391773

Hara, U. (2000). Bryozoan Fragments from Eocene Glacial Erratics of McMurdo Sound, East Antarctica. In J. Stilwell, \& R. M. Feldmann (Eds.), Paleobiology and Paleoenvironments of Eocene Rocks, McMurdo (pp. 321-323). Washington DC: American Geophysical Union, Antarctic Research Series 76. https://doi.org/10.1029/AR076p0321

Hara, U. (2001). Bryozoans from the Eocene of Seymour Island, Antarctic Peninsula. Palaeontologia Polonica, 60, 33-156.

Harmand, C., \& Cantagre, J. M. (1984). Le volcanisme alcalin tertiaire et quaternaire du Moyen atlas (Maroc): Chronologie K/Ar et cadre géodynamique. Journal of African Earth Sciences, 2, 51-55. https://doi.org/10.1016/0899-5362(84)90019-8

Harmand, C., \& Moukadiri, A. (1986). Synchronisme entre tectonique compressive et volcanisme alcalin: Exemple de la province quaternaire du Moyen Atlas (Maroc). Bulletin de la Société Géologique de France, 2, 595-603. https://doi.org/10.2113/gssgfbull.II.4.595

Hassall, A. H. (1841). Supplement to a Catalogue of Irish Zoophytes. Annals and Magazine of Natural History, 7, 363-373. https://doi.org/10.1080/03745484109442710

Herbig, H. G. (1991). Das Paläogen am Südrand des zentralen Hohen Atlas und in Mittleren Atlas Marokkos. Stratigraphic, Fazies, Paläogeographie und Paläotektonik. Berlin Geologica Abhandlungen (A) (vol. 135, pp. 1-289). Thesis. 
Herbig, H. G. (1993). Stratigraphy, Facies, and Synsedimentary Tectonics of Post-Middle Eocene Tertiary, Middle-Atlas West of Boulemane (Morocco). Neues Jahrbuch für Geologie und Paläontologie, 188, 1-50.

Herbig, H. G., \& Fechner, G. G. (1994). Cretaceous and Early Tertiary Stratigraphy, Facies and Palynology of the Eastern Bou Angueur Syncline, Middle Atlas Mountains, Morocco. Zeitschrift der Deutschen Geologischen Gesellschaft, 145, 249-273. https://doi.org/10.1127/zdgg/145/1994/249

Herbig, H. G., \& Trappe, J. (1994). Stratigraphy of the Subatlas Group (Maastrichtian-Middle Eocene, Morocco). Newsletter on Stratigraphy, 30, 125-165. https://doi.org/10.1127/nos/30/1994/125

Holcová, K., \& Zágoršek, K. (2008). Bryozoa, Foraminifera and Cal-Careous Nannoplankton as Environmental Proxies of the Âoebryozoan Eventâ in the Middle Miocene of the Central Paratethys (Czech Republic). Palaeogeography Palaeoclimatology Palaeoecology, 267, 216-234. https://doi.org/10.1016/j.palaeo.2008.06.019

Juidette, M. (2000). Les épisodes carbonatés méso-cénozoïques du Moyen Atlas et de la haute Moulouya: Sédimentogenèse, Diagenèse polyphasée et contexte dynamique (p. 232). Thèse de 3ème cycle, Rabat: Univ. Mohammed V.

Jullien, J. (1888). Bryozoaires. Mission scientifique du Cap Horn 1882-1883. Zoologie, Part III, 6, 1-92.

Key, M. M., Burkhart, M. S., \& O’Leary, M. (2019). Eocene Bryozoans Preserved in Chert from the Wilson Bluff Limestone, Eucla Basin, Western Australia (pp. 85-90). Australasian Palaeontological Memoirs 52.

Linnaeus, C. (1758). Systema Naturae (Ed. 10, 1: 1e824).

MacGillivray, P. H. (1869). Descriptions of Some New Genera and Species of Australian Polyzoa; to Which Is Added a List of Species Found in Victoria. Transactions and Proceedings of the Royal Society of Victoria, 9, 126-148.

MacGillivray, P. H. (1885). Polyzoa. In F. McCoy (Ed.), Prodromus of the Zoology of Victoria, Volume II, Decade XI (pp. 17-36, plates 105-108). Melbourne: Government Printer.

Martha, S. O., Niebuhr, B., \& Scholz, J. (2016). Cheilostome Bryozoans. Journal of Central Europeen Geology: Geologica Saxonica, 62, 11-52.

Masetti, D., Figus, B., Jenkyns, H. C., Barattolo, F., Mattioli, E., \& Posenato, R. (2016). Carbon-Isotope Anomalies and Demise of Carbonate Platforms in the Sinemurian (Early Jurassic) of the Tethyan Region: Evidence from the Southern Alps (Northern Italy). Geological Magazine, 154, 625-650. https://doi.org/10.1017/S0016756816000273

McKinney, F. K., \& Taylor, P. D. (2003). Palaeoecology of Free-Lying Domal Bryozoan Colonies from the Upper Eocene of Southeastern USA. Acta Palaeontologica Polonica, $48,447-462$.

Mebrouk, F., Tabuce, R., Cappetta, H., \& Fei, M. (2009). Charophytes du Crétacé/Paléocène du Moyen-Atlas (Maroc): Systématique et implications biochronologiques. Revue de Micropaleontology, 52, 131-139. https://doi.org/10.1016/j.revmic.2007.08.003

Mouflih, M. (2015). Les phosphates du Maroc central et du Moyen Atlas (Maastrichtien Lutétien): Sédimentologie, stratigraphie séquentielle, contexte génétique et valorisation (p. 351). Thèse Doctorat d'Etat, Marrakech: Univ. Cadi Ayyad.

Mouflih, M., Samih, A., Chellai, E. H., Pascal A., Benbouziane, A., Aklil, A., Jahroud, N., Sebti, S., Amarghzaz, M., Bouya, B., \& Mchichi, M. (2006). Les Cortèges Phosphatés et Bitumineux du Moyen Atlas: Contexte Sédimentologique et Génétique. Notes et Mémoires du Service Géologique du Maroc, 514, 57-64. 
Moukadiri, A. (1983). Les enclaves ultrabasiques associées aux basaltes alcalins dans le district volcanique d'Azrou Timahdite (Moyen Atlas, Maroc) (p. 150). Thèse 3èmeCycle, Clermont-Ferrand Il.

Mountaj, S., Remmal, T., Lakroud, K., Boivin, P., El Hassani el Amrani, I. E., El Kamel, F., Makhoukhi, S., Jounaid, H., Amraoui, F., \& Soufi, M. (2019). The Volcanic Field of the Middle Atlas Causse: Highlights and Heritage Appropriation. The Geographical Bulletin, 60, 127-147.

Muftah, A. M., \& El-Safori, M. (2019). Taxonomy of Miocene Bryozoans from As Sahabi Area, Ajdabiyah Trough, NE Sirt Basin, Libya. Libyan Journal of Science \& Technology, 9, 155-164.

Preto, N., Breda, A., Dal Corso, J., Franceschi, M., Rocca, F., Spada, C. et al. (2017). The Loppio Oolitic Limestone (Early Jurassic, Southern Alps): A Prograding Oolitic Body with High Original Porosity Originated by a Carbonate Platform Crisis and Recovery. Marine and Petroleum Geology, 79, 394-411.

https://doi.org/10.1016/j.marpetgeo.2016.10.027

Rosso, A., \& Sanfilippo, R. (2000). Shallow-Water Bryozoans and Serpuloideans from Ross Sea, Terra Nova Bay, Antarctica. In F. M. Faranda, L. Guglielmo, \& A. Ianora (Eds.), Ross Sea Ecology (pp. 515-525). Berlin: Springer-Verlag. https://doi.org/10.1007/978-3-642-59607-0 37

Rychlinski, T., Uchman, A., \& Gaździcki, A. (2018). Lower Jurassic Bahamian-Type Facies in the Choč Nappe (Tatra Mts, West Carpathians, Poland) Influenced by Palaeocirculation in the Western Tethys. Facies, 64, 15. https://doi.org/10.1007/s10347-018-0528-1

Ryland, J. S., \& Hayward, P. J. (1977). British Anascan Bryozoans (pp. 1-188). Synopsis of the British Fauna (New Series), 10.

Solak, C., Tasli, K., \& Koç, H. (2017). Biostratigraphy and Facies Analysis of the Upper Cretaceouse Danian? Platform Carbonate Succession in the Kuyucak Area, Western Central Taurides, S Turkey. Cretaceous Research, 79, 43-63. https://doi.org/10.1016/j.cretres.2017.06.019

Termier, H. (1936). Etudes géologiques sur le Maroc central et le Moyen Atlas septentrional. Notes et Mém. Serv. Mines et cartes géologiques. Maroc, $\mathrm{n}^{\circ} 33$, tome IX.

Waeschenbach, A., Cox, C. C., Littlewood, D. T. J., Porter, J. S., \& Taylor, P. D. (2009). First Molecular Estimate of Cyclostomes Bryozoan Phylogeny Confirms Extensive Homoplasy among Skeletal Characters Used in Traditional Taxonomy. Molecular Phylogenetics and Evolution, 52, 241-251. https://doi.org/10.1016/j.ympev.2009.02.002

Winston, J. E. (2004). Bryozoans from Belize (pp. 1-14). Atoll Research Bulletin 523.

Ziko, A., Eweda, S. H., \& El-Khawaga, S. (2010). Middle Miocene Cyclostomatous Bryozoans from Cyrenaica, North Western Desert, Egypt. Paleontological Journal, 10, 61-106.

Ziko, A., Eweda, S., \& El-Khawaga, S. (2016). Extant Cheilostomatous Bryozoans of the Middle Miocene from the north Western Desert, Egypt. Journal of African Earth Sciences, 124, 12-31. https://doi.org/10.1016/j.jafrearsci.2016.08.012 